\title{
Association between licit drugs, physical activity and health-related quality of life in adolescents in northern Brazil
}

Associação entre drogas lícitas, atividade física e qualidade de vida relacionada à saúde em adolescentes no norte do Brasil

Asociación entre drogas legales, actividad física y calidad de vida relacionada con la salud en adolescentes del norte de Brasil

Raylane Carneiro de Sousa ${ }^{1}$ Alesandra Araújo de Souza'

Wagner Rodrigues Martins ${ }^{2}$ Alexandre Lima de Araújo Ribeiro ${ }^{3}$ Eduarda Cristina da Costa Silva ${ }^{4}$ Helizangela Morais Milhomem ${ }^{1}$ Joana Marcela Sales de Lucena ${ }^{1 *}$

\section{Resumo}

A adolescência é um período em que ocorrem várias transformações e formação de identidade, tornando o adolescente vulnerável a situações de risco. Portanto, este estudo teve como objetivo verificar a associação entre uso de drogas lícitas, atividade física e qualidade de vida relacionada à saúde em adolescentes do Ensino Médio de Tocantinópolis (Brasil). Cento e sessenta e dois adolescentes (idade de 16,3; DP $=1,7$ anos) responderam um questionário com informações sociodemográficas, tempo de atividade física e de comportamentos sedentários e uso de cigarro e álcool. A QVRS foi avaliada por meio do KIDSCREEN-27. Como resultado, a prática de atividade física entre adolescentes esteve significativamente associada apenas aos domínios do bem-estar físico $(\beta=0,003 ; p<0,001)$ e ao domínio do apoio social e grupo de pares $(\beta=0,002$; $\mathrm{p}<0,012$ ). Além disso, os adolescentes que relataram não fumar e não consumir bebidas alcoólicas tiveram quatro vezes mais chances de ter uma melhor percepção da qualidade de vida no domínio do bem-estar físico $(\mathrm{OR}=4,06 ; \mathrm{p}<0,001)$. Em conclusão, adolescentes fisicamente ativos, que não consumem bebida álcoolica e não fumam, apresentaram melhor QVRS.

Palavras-chave: Jovens. Fumar Cigarro. Tabagismo. Consumo de Bebidas Alcoólicas. Exercício físico.

\begin{abstract}
Adolescence is a period in which several transformations and identity formation occur, making adolescents vulnerable to risky situations. Therefore, this study aimed to verify the association between physical activity, health-related quality of life (HRQoL) and use of licit drugs by high school adolescents in Tocantinopolis (Brazil). One hundred and sixty-two adolescents (aged 16.3; $\mathrm{SD}=1.7$ years old) answered a questionnaire with sociodemographic information, time of physical activity and of sedentary behaviors and use of cigarettes and alcohol. The HRQoL was assessed through the KIDSCREEN-27. As a result the practice of physical activity among adolescents was significantly associated only with the domains of physical well-being $(\beta=0.003$; $\mathrm{p}<0.001)$ and with the domain of the social support and peer group $(\beta=0.002$; $p<0.012)$. In addition, the adolescents who reported not smoking and not consuming alcoholic beverages were four times more likely to have a better perception of quality of life in the domain of physical well-

1. Physical Education Degree Course, Federal University of Tocantins - UFT, Tocantins, Brazil. 2. Universidade of Brasília, Department of Physiotherapy, Campus Ceilândia - UnB, Brasília, Brazil. 3. Universidade of Brasília, Physical Education College, Campus Darcy Ribeiro - UnB, Brasília, Brazil. 4. Programa Associado de Pós-Graduação em Educação Física - UPE/UFPB, João Pessoa, Paraíba, Brasil. Corresponding author: Joana Marcela Sales de Lucena, e-mail: joanamarcelasales@hotmail.com . Este conteúdo utiliza a Licença Creative Commons Attribution 4.0 International License Open Access. This content is licensed
\end{abstract} under a Creative Commons attribution-type BY ISSN 2595 - 0096. 
being $(\mathrm{OR}=4.06 ; \mathrm{p}<0.001)$. In conclusion, physically active adolescents, who do not drink alcohol and do not smoke, had better HRQoL.

Keywords: Young, Cigarette, Cigar Smoking, Alcohol Drinking, Physical Exercise.

\section{Resumen}

La adolescencia es un período en el que se producen diversas transformaciones y formación de identidades que hacen que los adolescentes sean vulnerables a situaciones de riesgo. Por lo tanto, este estudio tuvo como objetivo verificar la asociación entre la actividad física, la calidad de vida relacionada con la salud (CVRS) y el uso de drogas legales en adolescentes de secundaria en Tocantinopolis (Brasil). Ciento sesenta y dos adolescentes (16,3 años; DT $=1,7$ años) respondieron el cuestionario con información sociodemográfica, tiempo de actividad física y conductas sedentarias y consumo de cigarrillos y alcohol. La CVRS se hizo cumplir a través del KIDSCREEN-27. Como resultado, la práctica de actividad física entre adolescentes se asoció significativamente solo con los dominios de bienestar físico $(\beta=0,003 ; p<0,001)$ y con el dominio de apoyo social y grupo de pares $(\beta=0,002 ; p<0,012)$. Además, los adolescentes que informaron no fumar y no beber bebidas alcohólicas tenían cuatro veces más probabilidades de tener una mejor percepción de la calidad de vida en el dominio del bienestar físico $(\mathrm{OR}=4.06$; $\mathrm{p}<0.001)$. En conclusión, los adolescentes físicamente activos, que no beben alcohol y no fuman, tienen mejor CVRS.

Palabras-clave: Juventud. Cigarrillo. Tabaquismo. Consumo de bebidas alcohólicas. Ejercicio físico.

\section{Introduction}

Adolescence is a phase in which many important changes in life occur, as it is a moment of searching for ideologies and identity formation, usually through the social approval found in groups of friends ${ }^{1}$ and also due to the occurrence of physical, psychological and social changes ${ }^{2}$. There are problems in the family sphere, such as a history of drug use by parents or abuse in the family ${ }^{3}$ and in the social sphere, such as the influence of friends who use psychoactive substances, which can lead adolescents to use drugs such as alcohol and cigarettes ${ }^{4}$.

$$
\text { Psychoactive substances are }
$$

classified as legal and illegal drugs and, regardless of type, the use of these substances by friends increases the chances of experimentation, causing frequent use and abuse ${ }^{5}$. The use of substances such as alcohol and cigarettes is associated with several factors that are detrimental to the life of an adolescent, namely: violent behavior ${ }^{6}$, lower school performance and difficulties to engage socially ${ }^{7}$, lower level of physical activity $^{8}$ and other experiences risk factors in childhood $^{9}$. In this sense, the consumption of alcohol and cigarettes can directly or indirectly affect the health-related quality of life (HRQoL) of this population.

HRQoL can be defined as a subjective and multidimensional construct ${ }^{10}$ and has a complex nature, which can be measured by individual tastes and influenced by social, cultural, religious and economic reasons ${ }^{11}$. HRQoL is directly linked to diseases and health interventions and refers to the impact of symptoms, lack of capacity 
or limitations in relation to progress and understanding about well-being ${ }^{12}$.

In this sense, several aspects will be influential in a person's HRQoL, among them, the practice of physical activities, since, when practiced brings several health-related benefits, they are immediate, such as improvement in general well-being associated with the release of hormones such as endorphins and improved socialization, are long-term, such as maintaining healthy behaviors and preventing future diseases ${ }^{13}$, consequently improving the HRQoL of $\operatorname{adolescents}^{14}$. The practice of physical activity can become even better, due to family influence, when parents are physically active and lead adolescents to adopt healthier behaviors ${ }^{15}$.

Studies carried out in countries in Europe $^{16}$, North America ${ }^{17}$ and Latin America $^{18}$ found that the practice of physical activity was associated with better HRQoL among adolescents; Other studies show that being physically active is associated with less alcohol consumption ${ }^{19}$. In Brazil, Gordia ${ }^{20}$ sought to find associations between the level of physical activity, alcohol consumption, body mass index and quality of life in young people aged 14 to 20 years, from the urban area of Paraná and the results showed that Brazilians who are physically inactive, possibly dependent on alcoholic beverages, obese and female, have a worse quality of life. And Rodrigues, Cheik and Mayer $(2008)^{21}$ related the use of cigarettes among adolescents and the level of physical activity in the city of Gurupi/Tocantins/Brazil, however, this study was carried out only with university students. Considering the different dynamics of life between the countryside or the countryside and between the period of adolescence and entry into a university, there are important gaps to be filled; One about different behaviors acquired according to the environment and culture that the adolescent is inserted in: the data on health and quality of life from early childhood to old age in the Northern region of Brazil are unknown; The other refers to habits acquired in adolescence that drag on for the rest of their lives, such as use of legal drugs and physical activity by adolescents in the same region.

Additionally, studies carried out in Brazil were limited to verifying the association between physical activity, HRQoL and alcohol or cigarette consumption without, however, further investigating the moderating factors of this relationship $^{19}$. The concept of statistical moderation is analogous to that of interaction, it occurs when the relationship between two variables undergoes modification in the presence of a third variable, called a modifying or moderating variable $^{22}$. Practicing physical activities and consuming legal drugs are behaviors that are associated with the HRQoL of adolescents, and it is important to understand if they are related attitudes or if they have different effects on HRQoL, especially in a socially 
unequal country and different levels of access to information.

Therefore, this study aimed to verify the association between use of legal drugs, physical activity and HRQoL and to verify whether the effect of physical activity on health-related quality of life is moderated by the consumption of alcohol and drugs by high school adolescents. de Tocantinópolis, Tocantins, Brazil.

\section{Methods}

This study is a cross-sectional study, approved by the Ethics and Human Research Committee of the Federal University of Tocantins - UFT (CAAE: 91494418.3.0000.5519). Data were collected in the second semester of 2018 and the first semester of 2019. The city of Tocantinópolis, site of this study, is a small riverside municipality, located in the Bico of Parrot region, in the interior of the state of Tocantins, Brazil, with population estimated at 22,870 inhabitants, Human Development Index (HDI) of 0.681 and GDP per capita (2017) of R $\$ 12,708.47$ reais $^{23}$.

\section{Sample}

The population of this study were adolescents from the 1st and 3rd year of high school, from the morning, afternoon and full shifts, from state public schools in the urban area of Tocantinopolis. These series were chosen because it is a possible moment when these risk behaviors and identity formation begin. The sample was selected by a singlestage cluster. All state schools in
Tocantinopolis that have high school were selected, with a total of three schools. Subsequently, classes from the 1st and 3rd year of High School were selected to participate in the research. Considering the number of high schools in the city, all were considered eligible to participate in the study.

\section{Instruments}

To collect the variables, a questionnaire was used, applied in the form of a structured interview, which contained questions about sociodemographic information, use of legal drugs (cigarettes and alcohol), physical activity, HRQoL, anthropometric measures (Body Mass Index - BMI) and sedentary behaviors. Sociodemographic variables included questions about sex (female or male), age (in years), name of individual, address, educational level of parents, being: Illiterate or up to the 3rd grade of elementary school; 4th grade of Fundamental; Elementary (complete and incomplete); Medium (complete and incomplete); Superior (complete and incomplete).

HRQoL was assessed by KIDSCREEN - 27. This questionnaire has already been validated for Brazilian adolescents, the instrument had total internal consistency (Cronbach's $\alpha=0.92)^{24}$. It contains 27 items distributed in five dimensions: physical well-being (five items); psychological well-being (seven items); autonomy and relationship with parents 
(seven items); friends and social support (four items); and school environment (four items). All items were anchored with a fourpoint Likert scale (never $=1$; rarely $=2$; often = 3; always $=4$ ). The variable HRQoL and its domains were treated as a score, adopting the following procedure: $\left(\sum\right.$ of the items in the questionnaire / domain) x $100 /$ (number of items $\mathrm{x}$ number of points on the scale of the items / domain). Thus, the HRQoL score varied from 27, indicating the lowest level of HRQoL, to 100, indicating the highest level.

For information about legal drugs, questions were asked related to alcohol and cigarette consumption in the last 30 days. The following question was used: "In the last 30 days on how many days did you consume a dose of alcohol" ${ }^{25}$ and "In the last 30 days on how many days did you smoke? ${ }^{26}$.

Physical activity was measured using a questionnaire, which was tested in a similar population and has good "test-retest" reproducibility values (intraclass correlation coefficient: $\mathrm{ICC}=0.88 ; 95 \% \mathrm{CI}: 0.84-0.91$ ) and moderate agreement to measure physical activity in two categories $(<300$ minutes / week vs. $\geq 300$ minutes / week, kappa index: $\mathrm{k}=0.52)$. The adolescents reported the frequency of practice (days / week) and the duration (minutes / day) of physical activities performed in the last week, based on a list of 20 activities, with the possibility of adding two more activities ${ }^{27}$.
To measure body mass, a digital scale, from the G-Tech ${ }^{\circledR}$ brand, was used with an accuracy of 100 grams. Height was measured using a portable stadiometer, attached to a wall without a footer. To measure height, the adolescent was instructed to position himself barefoot, with his back to the tape, with his feet together, his arms at his side, his spine erect and his knees not bending; the adolescent was asked to take a deep breath, at this time the height was measured by the evaluator. All anthropometric measurements were performed following the standards described by Lohman, Roche and Martorell ${ }^{28}$. BMI was determined by measures of body mass and height (body mass/height ${ }^{2}$ ). All measures were taken in triplicate and for the purpose of final result the average of the three measures was used.

The measurement of sedentary behaviors (television, computer, video games), took into account duration (hours per day) and frequency (number of days) on weekdays and weekends, considering the week prior to data collection. The final measurement was given in minutes / week, based on the following procedure: time, in minutes per day of the week, multiplied by the days of the week, added to the time per minute per weekend day, to obtain the average number of minutes / week that teenagers spent in front of television, computer and video games ${ }^{29}$. 


\section{Statistical analysis}

The data were entered into the Microsoft Excel 97 - 2003 program by a previously trained pair of students and subsequently checked by another pair of students in order to avoid and correct possible tabulation errors. For descriptive analysis of numerical variables, the calculation of the mean and standard deviation (SD) was used. For the variables measured on a nominal and ordinal scale, the frequency distribution was used.

The Kolmogorov - Smirnov test was applied to test the normality of the data; all HRQoL domains showed p >0.05, except for the general score and domain 1 . To verify the associations between physical activity, cigarette and alcohol use and the HRQoL score and their respective domains, multiple linear regression was used. The multiple linear regression model was adjusted for the variables sex, age, time in sedentary behavior and body mass index, regardless of the $p$ value found in the bivariate analysis. The input method for variables in the model was Backward. To assess the quality of the model's fit, the standardized residues and residues were generated and the normality of the residues was evaluated with the ShapiroWilk test, the multicollinearity test and the Cook-Weisberg test for heteroscedasticity.

Multiple logistic regression was used to analyze moderation. The analysis assumed that the relationship between physical activity and HRQoL could be moderated by the use of cigarettes or alcohol. The variable physical activity was categorized as physically active $=0$ and physically inactive $=1$. The variables use of alcohol and cigarette use were recategorized as $0=$ do not use drink / cigarette and $1=$ use drink / cigarette. The quality of life domains that had a significant association in the multiple linear regression model were analyzed and their scores were divided into two categories, 0 to 50 points $=0$ and 51 to $100=1$. The general HRQoL score was not assessed every participants had a score greater than 50, and it is not possible to divide them into two groups. The logistic regression model was adjusted for the following covariables: sex, age, body mass index and time in sedentary behavior (minutes / week). The Mantel-Haenzel test was used to define whether there was an interaction. The analyzes were performed using the Stata 13.0 statistical program. For all analyzes, a significance level of less than $5 \%(\mathrm{p}<0.05)$ was adopted.

\section{Results}

There were 483 students enrolled in high school in the public schools of Tocantinopolis, Tocantins, Brazil in the second semester of 2018 and the first semester of 2019, of these, 229 were considered losses, because they were not in school on the day of data collection, they were enrolled but not attend school regularly, characterizing students who are dropping out of school, or because they have 
a health problem that would prevent their participation; In addition, 92 students refused to participate; Finally, 162 students, aged 14 to 19 , answered the questionnaire, totaling the final sample of this study.

The average age of the students was 16.7 years old $(\mathrm{SD}=1.7)$, more than half of the sample is female (54.9\%), about $60 \%$ was classified in economic class $\mathrm{C}$ and has parents who studied from elementary school to high school $($ parents $=59.7 \%$; mothers $=$ $55.6 \%)$. Regarding the use of cigarettes and alcohol in the last 30 days prior to the study, most said they did not use cigarettes (98.7\%); Regarding the use of alcoholic beverages, $82.7 \%$ responded that they did not consume it on any day.

The average total time of physical activity, in minutes per week, was 1,329.8 $(\mathrm{SD}=1,502.9)$ and the average time in sedentary behaviors corresponded to 3,452.2 minutes per week $(\mathrm{SD}=3,426.5)$. The body mass index (BMI) averaged 20.9 $\mathrm{kg} / \mathrm{m}^{2}(\mathrm{SD}=3.89)$. In relation to HRQoL, an average general score of $78.5(\mathrm{SD}=11.9)$ was obtained; among its domains, autonomy and relationship with parents, social support and peer group and school environment, had similar averages, while the domains physical well-being and psychological wellbeing had lower means (table 1). Table 2 shows the chi-square analysis and Pearson's correlation among adolescents who reported drinking / not drinking and smoking / not smoking and sociodemographic variables, age and BMI. There was a statistically significant association between sex, age and level of physical activity.

Table 1. Sociodemographic characteristics, use of legal drugs, lifestyle, anthropometric variables and HRQoL of adolescents from Tocantinopolis (TO), in the years 2018/2019.

\begin{tabular}{|c|c|c|}
\hline Variables & $\mathbf{n}$ & $\%$ \\
\hline Total & 162 & 100 \\
\hline \multicolumn{3}{|l|}{ Genre } \\
\hline Boys & 73 & 45.1 \\
\hline Girls & 89 & 54.9 \\
\hline \multicolumn{3}{|l|}{ Economic class } \\
\hline $\mathrm{A} / \mathrm{B}$ & 38 & 23.6 \\
\hline $\mathrm{C}$ & 101 & 62.7 \\
\hline $\mathrm{D} / \mathrm{E}$ & 22 & 13.7 \\
\hline \multicolumn{3}{|l|}{ Father's schooling } \\
\hline $\begin{array}{l}\text { Illiterate / 4th grade of } \\
\text { Elementary }\end{array}$ & 46 & 35.7 \\
\hline $\begin{array}{l}\text { Elementary School to High } \\
\text { School }\end{array}$ & 77 & 59.7 \\
\hline $\begin{array}{l}\text { Higher Education (complete } \\
\text { and incomplete) }\end{array}$ & 6 & 4.6 \\
\hline \multicolumn{3}{|l|}{ Mother's schooling } \\
\hline $\begin{array}{l}\text { Illiterate / } 4 \text { th grade of } \\
\text { Elementary }\end{array}$ & 53 & 34.9 \\
\hline $\begin{array}{l}\text { Elementary School to High } \\
\text { School }\end{array}$ & 85 & 55.9 \\
\hline $\begin{array}{l}\text { Higher Education (complete } \\
\text { and incomplete) }\end{array}$ & 14 & 9.2 \\
\hline \multicolumn{3}{|l|}{ Cigarette use } \\
\hline No day & 154 & 98.7 \\
\hline One day or more & 2 & 1.3 \\
\hline \multicolumn{3}{|l|}{ Use of alcoholic beverages } \\
\hline No day & 137 & 87.2 \\
\hline \multirow[t]{2}{*}{ One day or more } & 19 & 12.2 \\
\hline & Average & SD \\
\hline Age & 16.3 & 1.7 \\
\hline \multicolumn{3}{|l|}{ Lifestyle } \\
\hline $\begin{array}{l}\text { Physical activity time } \\
\text { (min./week) }\end{array}$ & $1,346.6$ & $1,502.9$ \\
\hline \multicolumn{3}{|l|}{ Anthropometric variables } \\
\hline Body mass index $\left(\mathrm{kg} / \mathrm{m}^{2}\right)$ & 20.9 & 3.89 \\
\hline \multicolumn{3}{|l|}{ Health-related quality of life } \\
\hline Overall score & 78.9 & 11.9 \\
\hline Physical well-being & 56.4 & 13.6 \\
\hline Psychological well-being & 66.5 & 8.75 \\
\hline $\begin{array}{l}\text { Autonomy and Relationship } \\
\text { with Parents }\end{array}$ & 74.2 & 15.5 \\
\hline $\begin{array}{l}\text { Social support and Peer } \\
\text { group }\end{array}$ & 79.9 & 16.7 \\
\hline School environment & 75.6 & 14.6 \\
\hline
\end{tabular}


Multivariate analysis was performed among adolescents who reported not smoking $(\mathrm{n}=154)$. In the crude analysis, the practice of physical activity was associated with the general score of HRQoL, in the domain of physical well-being and in the domain of social support and group of peers. In the adjusted analysis, the practice of physical activity among adolescents was significantly associated only with the physical well-being domains $(\beta=0.003 ; p<0.001)$ and with the social support and peer group domains $(\beta=0.002 ; \mathrm{p}=0.012)$ (Table 3).

Among the adolescents who reported not consuming alcoholic beverages ( $\mathrm{n}=137)$, in the crude analysis physical activity was associated with the general score of HRQoL, in the physical well-being domain and in the social support and peer group domain, however, these associations lost significance after adjusting the model, with only the association with the general HRQoL score and the physical well-being domain (table 4).

Among the variables that had a significant result in the crude and adjusted linear regression, interaction was tested. For this, multiple linear regression was applied to groups that did not use drinks or tobacco. Since there was a difference between those who used and those who did not, interaction terms were constructed which, when inserted in a logistic regression analysis, showed significant results (use of interaction terms and Mantel-Haenzel test, table 5). The interaction analysis showed that adolescents who reported not smoking were 4 times more likely to have a better perception of quality of life in the physical well-being domain. A similar result was found among adolescents who reported not consuming alcoholic beverages, whose odds ratio was $4.06(\mathrm{p}=0.003)$ also in the physical wellbeing domain of HRQoL.

The final model presented good adjustment values, the residue evaluation was performed by the Shapiro-Wilk test and presented normal distribution $(\mathrm{p}=0.762)$, there was no multicollinearity between the variables $(\mathrm{VIF}=1.08)$ and the CookWeisberg for heteroscedasticity also demonstrated an adjusted model $(\mathrm{p}=0.656)$.

\section{Discussion}

This study aimed to verify the association between use of legal drugs, physical activity and HRQoL, and to verify whether the effect of physical activity on health-related quality of life is moderated by alcohol and cigarette consumption among adolescents. Associations between physical activities and HRQoL were found among adolescents who did not drink alcohol and did not smoke.

Sample characteristics such as prevalence of females, belonging to the middle economic class, age around 16 years and maternal education between elementary and high school (from 8 to 12 years of study) are compatible with characteristics of the region of study (Northern Brazil) presented 
by the Brazilian Institute of Geography and Statistics - IBGE (IBGE, 2017) and similar to those found in other studies with adolescents in Brazil ${ }^{7}$, Europe and Canada ${ }^{30,}$ ${ }^{31}$. The international report of the Health Behavior In School-Aged Children (HBSC Study) brings to light findings about health behaviors, well-being and health determinants of adolescents in Europe and Canada; Evidence gathered in recent decades shows that young people who grow up in disadvantaged social circumstances are exposed to greater health risks. Specifically, special attention should be paid to differences related to sex, social class and age. For example, the same report found earlier that belonging to wealthy families was an important predictor of youth health; in the last report of the same study, the findings showed that, at all ages, in all countries and regions studied, boys were more likely to be physically active than girls, the gender gap gap worsens with increasing age and that participation in physical activity decreases in older adolescents and with lower family income. These findings may indicate that social inequality in health may appear or worsen during adolescence, consolidate into adulthood and this has important implications for the right moment for health interventions (Inchley et al., 2020).

Brazilian studies also point to different results in physical activity, overweight and risk for cardiovascular disease, according to different socio- demographic characteristics of adolescents ${ }^{32}$. A study with a representative sample of Brazilian students from Southern Brazil indicated that the odds of overweight and obesity were higher among boys and girls in urban areas, adolescents with higher income had a higher chance of being overweight and obese in the second survey ${ }^{33}$. Another study, carried out with data from the National School Health Survey - PeNSE, aimed to analyze the association between sociodemographic factors and risk behaviors for cardiovascular health in Brazilian adolescents aged 13 to 17 years, indicated that there were associations between consumption of goodies, insufficient physical activity and experimentation with alcoholic beverages in female adolescents and consumption of soft drinks and cigarette use among male adolescents ${ }^{33}$. A study carried out in the North of the country indicated that younger adolescents who traveled to school by car, that is, less physically active, were more likely to be overweight $^{34}$.

In this research, it was noticed that the frequency of physical activity by students showed a high average ( $>3$ hours / day), exceeding the value recommended by the World Health Organization - $\mathrm{WHO}^{25}$, which is 60 minutes daily. Thus, most adolescents in this study were classified as physically active subjects. The level of physical activity was similar to the result of Farias Junior et al. ${ }^{27}$ carried out in the city of 
Table 2. Association between use of legal drugs, sociodemographic variables, physical activity and BMI of adolescents from Tocantinopolis (TO), in the years $2018 / 2019$.

\begin{tabular}{|c|c|c|c|c|c|c|c|c|c|c|}
\hline \multirow[t]{2}{*}{ Variables } & \multicolumn{2}{|c|}{ Don't drink } & \multicolumn{2}{|c|}{ Drink } & \multicolumn{3}{|c|}{ Don't smoke } & \multicolumn{2}{|c|}{ Smoke } & \multirow[b]{2}{*}{ p } \\
\hline & $\mathbf{n}$ & $\%$ & $\mathbf{n}$ & $\%$ & $\mathrm{p}$ & $\mathbf{n}$ & $\%$ & $\mathbf{n}$ & $\%$ & \\
\hline Genre & & & & & $0.03^{\circ}$ & & & & & 2.48 \\
\hline Boys & 62 & 45.3 & 9 & 47.4 & & 68 & 44.2 & 2 & 100 & \\
\hline Girls & 75 & 54.7 & 10 & 52.6 & & 86 & 55.8 & () & 0 & \\
\hline Economic class & & & & & 3.87 & & & & & 1.19 \\
\hline $\mathrm{A} / \mathrm{B}$ & 35 & 25.6 & 2 & 10.5 & & 36 & 23.4 & () & 0 & \\
\hline $\mathrm{C}$ & 85 & 62.0 & 12 & 63.2 & & 96 & 62.4 & 2 & 100 & \\
\hline $\mathrm{D} / \mathrm{E}$ & 17 & 12.4 & 5 & 26.3 & & 22 & 14.3 & 0 & 0 & \\
\hline Physical Activity & & & & & 0.02 & & & & & 0.88 \\
\hline Physically active & 106 & 77.4 & 15 & 78.9 & & 120 & 77.9 & 1 & 50.0 & \\
\hline Physically inactive & 31 & 22.6 & 4 & 21.1 & & 34 & 22.1 & 1 & 50.0 & \\
\hline & Average & SD & Average & SD & $\mathrm{p}$ & Average & SD & Average & SD & $\mathrm{p}$ \\
\hline Age & 128 & 1.66 & 19 & 1.42 & $<0.001^{\circ}$ & 145 & 1.66 & 2 & 1.41 & $<0.001^{+}$ \\
\hline BMI & 136 & 4.07 & 19 & 2.44 & 0.533 & 153 & 3.95 & 2 & 10.93 & 0.521 \\
\hline
\end{tabular}

Analysis of differences between groups $\left(\chi^{2}\right)$ for variables on a categorical scale and Pearson's correlation analysis for variables on a numerical scale. $\mathrm{BMI}=$ body mass index. ${ }^{*}=$ statistically significant values.

Table 3. Crude and adjusted linear regression analysis between physical activity and health-related quality of life and their respective domains stratified in adolescents who did not smoke, from high schools in urban areas in the city of Tocantinopolis (TO), in the years 2018/2019.

\begin{tabular}{|c|c|c|c|c|c|c|c|c|c|c|c|c|}
\hline & \multicolumn{12}{|c|}{ Health-related quality of life } \\
\hline \multirow[t]{2}{*}{ Variables } & \multicolumn{2}{|c|}{ Overall score } & \multicolumn{2}{|c|}{ Physical well-being } & \multicolumn{2}{|c|}{$\begin{array}{l}\text { Psychological well- } \\
\text { being }\end{array}$} & \multicolumn{2}{|c|}{$\begin{array}{c}\text { Autonomy and } \\
\text { Relationship with } \\
\text { Parents }\end{array}$} & \multicolumn{2}{|c|}{$\begin{array}{l}\text { Social support and } \\
\text { Peer group }\end{array}$} & \multicolumn{2}{|c|}{ School environment } \\
\hline & $\beta(\mathrm{SE})$ & $95 \% \mathrm{IC}$ & $\beta(\mathrm{SE})$ & $95 \% \mathrm{IC}$ & $\beta(\mathrm{SE})$ & $95 \% \mathrm{IC}$ & $\beta(\mathrm{SE})$ & $95 \% \mathrm{IC}$ & $\beta(\mathrm{SE})$ & $95 \% \mathrm{IC}$ & $\beta(\mathrm{SE})$ & $95 \% \mathrm{IC}$ \\
\hline \multicolumn{13}{|c|}{ Crude analysis } \\
\hline $\begin{array}{l}\text { Physical activity } \\
\text { (min./week) }\end{array}$ & $0.001(0.001)$ & $\begin{array}{c}0.001- \\
0.003\end{array}$ & $0.003(0.001)$ & $\begin{array}{l}0.002- \\
0.005\end{array}$ & $\begin{array}{c}0.001 \\
(0.001)\end{array}$ & $\begin{array}{l}-0.001- \\
0.002\end{array}$ & $\begin{array}{c}0.001 \\
(0.001)\end{array}$ & $\begin{array}{l}-0.001- \\
0.003\end{array}$ & $\begin{array}{c}0.003 \\
(0.001)\end{array}$ & $\begin{array}{l}0.001- \\
0.005\end{array}$ & $\begin{array}{l}-0.002 \\
(0.001)\end{array}$ & $\begin{array}{l}-0.003- \\
-0.001\end{array}$ \\
\hline \multicolumn{13}{|c|}{ Adjusted analysis } \\
\hline $\begin{array}{l}\text { Physical activity } \\
\text { (min./week) }\end{array}$ & $0.001(0.001)$ & $\begin{array}{c}0.001- \\
0.003\end{array}$ & $0.002(0.001)$ & $\begin{array}{l}0.002- \\
0.004^{*}\end{array}$ & $\begin{array}{c}0.001 \\
(0.001)\end{array}$ & $\begin{array}{l}-0.001 \\
-0.002\end{array}$ & $\begin{array}{c}0.001 \\
(0.001)\end{array}$ & $\begin{array}{l}-0.001 \\
-0.003\end{array}$ & $\begin{array}{c}0.002 \\
(0.001)\end{array}$ & $\begin{array}{l}0.001- \\
0.004^{*}\end{array}$ & $\begin{array}{l}-0.001 \\
(0.001)\end{array}$ & $\begin{array}{l}-0.003 \\
-0.001\end{array}$ \\
\hline
\end{tabular}

Analysis adjusted for sex, age, sedentary behaviors (minutes / week) and Body Mass Index. SE = Standard Error; ${ }^{*}=\mathrm{p}<0.05$.

Source: Research Group on Physical Activity and Chronic Diseases - GPAFD, 2019. 
Table 4. Analysis of crude and adjusted linear regression between physical activity and health-related quality of life and their respective domains stratified in adolescents who did not use alcohol, from high schools in urban areas in the city of Tocantinopolis (TO), in the years 2018/2019.

\begin{tabular}{|c|c|c|c|c|c|c|c|c|c|c|c|c|}
\hline \multirow{3}{*}{ Variables } & \multicolumn{12}{|c|}{ Health-related quality of life } \\
\hline & \multicolumn{2}{|c|}{ Overall score } & \multicolumn{2}{|c|}{ Physical well-being } & \multicolumn{2}{|c|}{ Psychological well-being } & \multicolumn{2}{|c|}{$\begin{array}{c}\text { Autonomy and } \\
\text { Relationship with } \\
\text { Parents }\end{array}$} & \multicolumn{2}{|c|}{$\begin{array}{l}\text { Social support and Peer } \\
\text { group }\end{array}$} & \multicolumn{2}{|c|}{ School environment } \\
\hline & $\beta(\mathrm{SE})$ & $95 \% \mathrm{IC}$ & $\beta(\mathrm{SE})$ & $95 \% \mathrm{IC}$ & $\beta(\mathrm{SE})$ & $95 \% \mathrm{IC}$ & $\beta(\mathrm{SE})$ & $95 \% \mathrm{IC}$ & $\beta(\mathrm{SE})$ & $95 \% \mathrm{IC}$ & $\beta(\mathrm{SE})$ & $95 \% \mathrm{IC}$ \\
\hline \multicolumn{13}{|c|}{ Crude analysis } \\
\hline $\begin{array}{l}\text { Physical activity } \\
\text { (min./week) }\end{array}$ & $\begin{array}{c}0.001 \\
(0.001) \\
\end{array}$ & $\begin{array}{c}0.001- \\
0.003 \\
\end{array}$ & $\begin{array}{c}0.003 \\
(0.001) \\
\end{array}$ & $\begin{array}{l}0.003- \\
0.005\end{array}$ & $\begin{array}{c}0.001 \\
(0.001) \\
\end{array}$ & $\begin{array}{c}-0.001- \\
0.002 \\
\end{array}$ & $\begin{array}{c}0.002 \\
(0.001) \\
\end{array}$ & $\begin{array}{c}0.001- \\
0.004\end{array}$ & $\begin{array}{c}0.002 \\
(0.001) \\
\end{array}$ & $\begin{array}{c}0.001- \\
0.005\end{array}$ & $\begin{array}{l}-0.002 \\
(0.001) \\
\end{array}$ & $\begin{array}{c}-0.004-- \\
0.001\end{array}$ \\
\hline \multicolumn{13}{|c|}{ Adjusted analysis } \\
\hline $\begin{array}{l}\text { Physical activity } \\
\text { (min./week) }\end{array}$ & $\begin{array}{c}0.001 \\
(0.001) \\
\end{array}$ & $\begin{array}{l}0.001- \\
0.002^{*}\end{array}$ & $\begin{array}{c}0.003 \\
(0.001)\end{array}$ & $\begin{array}{l}0.002- \\
0.005^{*}\end{array}$ & $\begin{array}{c}0.001 \\
(0.001) \\
\end{array}$ & $\begin{array}{c}-0.001- \\
0.002 \\
\end{array}$ & $\begin{array}{c}0.001 \\
(0.001) \\
\end{array}$ & $\begin{array}{c}-0.001- \\
0.003\end{array}$ & $\begin{array}{c}0.001 \\
(0.001)\end{array}$ & $\begin{array}{l}0.001- \\
0.004^{*}\end{array}$ & $\begin{array}{l}-0.001 \\
(0.001)\end{array}$ & $\begin{array}{c}-0.003- \\
0.001 \\
\end{array}$ \\
\hline
\end{tabular}

Analysis adjusted for sex, age, sedentary behaviors (minutes / week) and Body Mass Index. SE = Standard Error; ${ }^{*}=\mathrm{p}<0.05$.

Source: Research Group on Physical Activity and Chronic Diseases - GPAFD, 2019. 
Paraiba, Brazil, where most adolescents were classified as physically active, mainly male ${ }^{27}$. The high rate of physical activity found in this study may occur due to the lifestyle of the population studied; As it is a small city, with 22,619 inhabitants ${ }^{23}$, and does not offer collective transport to residents, most of them need to get around on foot from one place to another, which increases the time spent on physical activity in commuting.

The BMI of the adolescents in this study can be considered normal (20.9 kg / $\mathrm{m}^{2}$ ), which is possibly related to the fact that they remain physically active for more hours than recommended by the WHO. Apparently, even with all the metabolic changes, especially among girls, which may be unfavorable in relation to BMI, maintaining the lifestyle can be a positive point for maintaining a good body composition. It is possible that, being one of the full-time schools, the adoption of healthy behaviors among adolescents is better.

When asked about cigarette and alcohol consumption, it was found that the prevalence of use of these substances among adolescents was low. Similar results were found in the study of Cardoso and Malbegier $^{36}$ carried out in the municipality of Jacareí and Diadema (São Paulo, Brazil), which evaluated 965 children aged 10 to 18 years, among which 570 (62\%) declared not to use these substances. In contrast, a study carried out in Porto Velho, Roraima, Brazil with adolescents aged 12 to 13 years old showed that young people make excessive use of alcohol and cigarettes, and that the use of both is associated ${ }^{37}$ and the study of Nery et al. ${ }^{38}$, carried out with 540 adolescents in Teresina (Piaui, Brazil), indicated that more than $15 \%$ of adolescents consumed alcohol once or twice a week and $11 \%$ consumed up to two doses per week. The amount of daily doses of alcoholic beverages was significantly associated with the time spent watching television per week $(\mathrm{OR}=2,45 ; \mathrm{p}=0,040)$ and on the weekend $(\mathrm{OR}=2,05 ; \mathrm{p}=0,032)$. Apparently, the divergent results may indicate two lifestyle profiles: the profile of healthy behavior, with no use of alcohol and cigarettes, high physical activity time and good BMI; and the risk behavior profile: with excessive use of cigarettes and alcohol, physical inactivity and poor BMI.

Table 5. Multiple logistic regression analysis between physical activity, adolescents who did not smoke and did not drink and specific domains of HRQoL.

\begin{tabular}{|c|c|c|c|}
\hline Interaction variables & OR & IC 95\% & p value \\
\hline \multicolumn{4}{|c|}{ Physical Activity and Smoking } \\
\hline $\begin{array}{l}\text { Domain Physical well- } \\
\text { being }\end{array}$ & 4.91 & $2.02-11.92$ & $<0.001$ \\
\hline $\begin{array}{l}\text { Domain Social Support } \\
\text { and Peer Group }\end{array}$ & 1.64 & $0.47-5.71$ & 0.434 \\
\hline \multicolumn{4}{|c|}{ Physical Activity and Drinking } \\
\hline $\begin{array}{l}\text { Domain Physical well- } \\
\text { being }\end{array}$ & 4.06 & $1.61-10.19$ & 0.003 \\
\hline
\end{tabular}

$\mathrm{OR}=$ odds ratio; IC 95\% = confidence interval $95 \%$.

Lifestyles can be determined by health-related beliefs, attitudes and behaviors, which are generated through knowledge produced through social representations ${ }^{39}$. The theory of social representations operationalizes a concept to work with social thinking in its dynamics and 
diversity and is based on the premise that there are different ways of knowing and communicating, guided by different objectives. This conception refers to social practices, and they can be expressed in health care behaviors. The health care behaviors of each individual can act as determinants of their health status. However, these determinants are affected by a set of processes, both personal and social, and will certainly interfere with that individual's HRQoL ${ }^{39}$.

Regarding HRQoL, it was observed that adolescents had a satisfactory perception in relation to the general context of HRQoL (general score $=78.5$ ). Brazilian studies, such as the one by Agatão, Reichenheim and Moraes $^{40}$, carried out with 807 adolescents between 10 and 17 years old, from Niterói (RJ), obtained similar results, the students had a positive HRQoL, with lower values only in the dimension of autonomy and relationship with parents 45 . It is possible that this result is related to the adoption of healthy habits, such as physical activity and abstaining from the use of legal drugs. Reinforcing this hypothesis, the study by Muros et al. ${ }^{31}$ carried out in Spain with 456 adolescents aged 11 to 14 years, found that having healthy lifestyle behaviors are reasonably good predictors for HRQoL in adolescence, being physical activity is the element with the greatest influence.

The time of physical activity was associated with better physical well-being in non-smoking students. This association can be established due to the health benefits of physical activity, such as greater physiological efficiency, weight maintenance, reduced risk of early death ${ }^{41}$ and can help in the prevention and treatment of numerous diseases, bringing well-being to those who practice it. According to the results found in this research, the fact of not smoking can also contribute to a better physical well-being, however, studies with adolescents verified the association between cigarettes and QoL, and no specific studies on HRQoL were found, which limits the comparison of results. In addition, the use of cigarettes causes harmful health effects, causing cardiovascular diseases, various types of cancer and lung diseases. Thus, not consuming cigarettes is a way to avoid possible complications caused by their use, and thus, not compromising physical wellbeing. Another explanation is the large number of advertisements that encourage people to adopt a healthier lifestyle, and that students have the time allocated to Physical Education classes at school, making them more physically active and leading them to choose habits that contribute to your health.

Among students who practice physical activity and do not smoke, physical activity was associated with the domain social support and group of peers. A study with 370 students, with an average age of 17 years old, concluded that family conflicts/problems induce adolescents to consume tobacco as a 
way of responding to family stress or as a way to affirm their opposition to parental figures $^{42}$, therefore, it is presumably that a home where there are many family disagreements, is more conducive to young people who have joined the use of cigarettes. Otherwise it may also be true, teenagers who have social support can adopt healthier habits. According to Antunes and Fontaine ${ }^{43}$, social support is, in fact, as an emotional or practical support offered by family and / or friends in the form of affection, company, assistance and information, everything that makes the individual feel loved, esteemed, careful, valued and safe. It is likely that the adolescents in this research will feel more accepted and recognized in the family and friendship circles. In addition, physical activity stimulates social interaction, which facilitates the creation of bonds of friendship, so it is possible that, in this sample, adolescents have companies that adopt healthy habits, such as practicing physical activity and abstaining from smoking, and this is reflected in a good support network and social support for healthy practices.

In this study, being physically active was associated with a better overall score, better physical well-being and better social support among adolescents who did not consume alcohol. In a study conducted with high school adolescents, Benincasa ${ }^{4}$ assesses the QoL and drug use among these students, and uses the idea that the more drugs are used, the lower the QoL will be. As HRQoL is a dependent variable, if adolescents were to make excessive use of alcohol, they could have some physical damage, just as it happens in athletes. Nery et al. ${ }^{45}$, in his study on the use of alcohol in physical exercise, explains that the excessive use of this substance causes adverse damage to fitness and physical performance, and consequently would affect HRQoL. Therefore, the less adolescents consume alcohol, or do not consume it, the greater the HRQoL, and when linked to the practice of physical activity, its tendency is to improve more and more.

This research had as its strong point the sample size (162 adolescents), which covered all high schools in the urban area, which shows a more pronounced reality of the adolescents' lifestyle in this school phase, regarding the practice physical activity, use of legal drugs and HRQoL. However, the present study has some limitations, as QoL is still studied in general, and therefore, few studies have been found that deal with HRQoL and its respective domains in adolescents, mainly associating the use of legal drugs and physical activity. In addition, in the search for studies using the KIDSCREEN-27, few studies were found to apply it to healthy adolescents, most of which were carried out on children and adolescents with chronic diseases. The cross-sectional design of this study also limits research on the determinants of HRQoL and the possibly existing causal relationship. 


\section{Conclusions}

Physically active adolescents, who do not drink alcohol and do not smoke, had better HRQoL, especially in the domains of physical well-being, social support and peer group. It is inferred that adopting healthy habits, such as being physically active and not consuming legal drugs, provides better

\section{HRQoL.}

\section{References}

1. Cavalcante MBPT, Alves MDS, Barroso MGT. Adolescência, álcool e drogas: uma revisão na perspectiva da promoção da saúde. Escola Anna Nery. 2008 12(3):555-9. doi: 10.1590/S1414-81452008000300024.

2. Alavarse GMA, Carvalho MDB. Álcool e adolescência: o perfil de consumidores de um município do norte do Paraná. Escola Anna Nery. 2006 10(3):408-16. doi: 10.1590/S141481452006000300008 .

3. Tavares BF, Béria JU, Lima MS. Fatores associados ao uso de drogas entre adolescentes escolares. Revista de Saúde Pública. 2004 38:787-96. doi: $10.1590 /$ S003489102004000600006.

4. Medeiros EH, Fisberg M. Adolescência... Quantas dúvidas! 1 ed. São Paulo: Atheneu; 2004.

5. Zeitoune RCG, Ferreira VS, Silveira HS, Domingos AM, Maia AC. El conocimiento de los adolescentes sobre drogas lícitas e ilícitas: una contribución para la enfermería comunitaria. Escola Anna Nery. 2012 16(1):5763. doi: 10.1590/S1414-81452012000100008.

6. Moura NA, Monteiro ARM, Freitas RJM. Adolescentes usuários de drogas (i)lícitas e práticas de violência. Revista de Enfermagem UFPE. 2016 10(5). doi: 10.5205/reuol.900378704-1-SM.1005201614.

7. Sousa BOP, Stelko-Pereira AC, Chaves ECL, Silva DM, Santos MA, Pillon SC. Drug use and risk factors among school adolescents. Acta Scientiarum Health Sciences. 2017 39(2):23340. doi: 10.4025/actascihealthsci.v39i2.32450.

8. Nduaguba SO, Ford KH, Rascati K. The role of physical activity in the association between smoking status and quality of life. Nicotine and Tobacco Research. 2019 21(8):1065-71. doi: 10.1093 / ntr / nty052.
9. Gonçalves H, Soares ALG, Santos APG, Ribeiro CG, Bierhals IO, Vieira LS, et al. Adverse childhood experiences and consumption of alcohol, tobacco and illicit drugs among adolescents of a Brazilian birth cohort. Cadernos de Saúde Pública. 2016 32:e00085815. doi: $\quad 10.1590 / 0102-$ $311 X 00085815$.

10. Harding L. Children's quality of life assessments: a review of generic and health related quality of life measures completed by children and adolescents. Clinical Psychology \& Psychotherapy: An International Journal of Theory \& Practice. 2001 8(2):79-96. doi: 10.1002/cpp.275.

11. Gomes MCS, Marques JL, Pinto MLR, Castro E, Gomes P, Gomes G, Belbute J. A multidimensionalidade do conceito de qualidade de vida. Sociedade e Território. 2008 42:135-44.

12. Seidl EMF, Zannon CMLC. Qualidade de vida e saúde: aspectos conceituais e metodológicos. Cadernos de Saúde Pública. 2004 20:580-8. doi: 10.1590/S0102311 X2004000200027.

13. Silva PVC, Costa Júnior AL. Efeitos da atividade física para a saúde de crianças e adolescentes. Revista Psicolgia Argumento. 2011 29(64):41-50. doi: 10.7213/rpa.v29i64.19915.

14. Silva RS, Silva I, Silva RA, Souza L, Tomasi E. Atividade física e qualidade de vida. Ciência \& Saúde Coletiva. 2010 15:115-20. doi: 10.1590/S1413-81232010000100017.

15. Seabra AF, Mendonça DM, Thomis MA, Anjos LA, Maia JA. Determinantes biológicos e sócio-culturais associados à prática de atividade física de adolescentes. Cadernos de Saúde Pública. 2008 24:721-36. doi: 10.1590/S0102-311X2008000400002.

16. Lourosa APM. Qualidade de vida em adolescentes de 10-12 anos: relação com a aptidão física e os níveis de actividade física [tese de doutorado]. Universidade de Trás os montes e Alto Douro; 2011.

17. Eddolls WT, McNarry MA, Lester L, Winn CO, Stratton G, Mackintosh KA. The association between physical activity, fitness and body mass index on mental well-being and quality of life in adolescents. Quality of Life Research. 2018 27(9):2313-20. doi: 10.1007 / s11136-018-1915-3.

18. Palomino-Devia C, Reyes-Oyola FA, Sánchez-Oliver A. Levels of physical activity, health-related quality of life, physical self-concept and body-mass index among Colombian 
students. Biomedica. 2018 38(2):224-31. doi: 10.7705 / biomedica.v38i0.3964.

19. Edwards MK, Loprinzi PD. Comparative effects of meditation and exercise on physical and psychosocial health outcomes: A review of randomized controlled trials. Postgraduate Medicine. 2018 130(2):222-8. doi: 10.1080/00325481.2018.1409049.

20. Gordia AP. Associação da atividade física, consumo de álcool e índice de massa corporal com a qualidade de vida de adolescentes [dissertação de mestrado]. Universidade Federal do Paraná (UFPR); 2008.

21. Rodrigues ESR, Cheik NC, Mayer AF. Nível de atividade física e tabagismo em universitários. Revista de Saúde Pública. 2008 42:672-8. doi:
89102008000400013.

22. Bauman AE, Sallis JF, Dzewaltowski DA, Owen N. Toward a better understanding of the influences on physical activity: the role of determinants, correlates, causal variables, mediators, moderators, and confounders. American Journal of Preventive Medicine. 2002 23(2):5-14. doi: 10.1016 / s0749-3797 (02) 00469-5.

23. IBGE. População: Tocantinópolis. $2017 . \quad$ Available from: https://cidades.ibge.gov.br/brasil/to/tocantinopol is/panorama.

24. Farias Júnior JC, Loch MR, Lima Neto AJ, Sales JM, Ferreira FELL. Reprodutibilidade, consistência interna e validade de construto do KIDSCREEN-27 em adolescentes brasileiros. Cadernos de Saúde Pública. 2017 33:e00131116. doi: $10.1590 / 0102-$ $311 \times 00131116$.

25. Bezerra J, Barros MVG, Tenório MCM, Tassitano RM, Barros SSH, Hallal PC. Religiosidade, consumo de bebidas alcoólicas e tabagismo em adolescentes. Rev Panam Salud Publica. 2009;26(5):440-6.

26. Farias Júnior JC, Nahas MV, Barros MVG, Loch MR, Oliveira ES, Bem MFL et al. Comportamentos de risco à saúde em adolescentes no Sul do Brasil: prevalência e fatores associados. Rev Panam Salud Publica. 2009;25(4):344-52. doi: 10.1590/S102049892009000400009.

27. Farias Júnior JC, Lopes AS, Mota J, Santos MP, Ribeiro JC, Hallal PC. Validade e reprodutibilidade de um questionário para medida de atividade física em adolescentes: uma adaptação do Self-Administered Physical Activity Checklist. Revista Brasileira de
Epidemiologia. 2012 15:198-210. doi: 10.1590 / S1415-790X2012000100018.

28. Lohman TG, Roche AF, Martorell R. Anthropometric standardization reference manual: Human kinetics books Champaign; 1988.

29. Lucena JMS, Loch MR, Silva ECC, Farias Júnior, JC. Sedentary behavior and healthrelated quality of life in Brazilian adolescents. Ciência e Saúde Coletiva [Pré-impressão]. (2021/Ago). [Citado em 17/08/2021]. Disponível em

http://www.cienciaesaudecoletiva.com.br/artigos /sedentary-behavior-and-healthrelated-quality-oflife-in-brazilian-adolescents/18180.

30. Inchley J, Currie D, Budisavljevic S, Torsheim T, Jåstad A, Cosma A. Spotlight on adolescent health and well-being. Findings from the 2017/2018. Health Behaviour in Schoolaged Children (HBSC) survey in Europe and Canada. International Report. 2020 v.1. Key findings. Copenhagen: WHO Regional Office for Europe.

31. Muros JJ, Pérez FS, Ortega FZ, Sánchez VMG, Knox E. Associação entre comportamentos de estilo de vida saudável e a qualidade de vida relacionada à saúde entre adolescentes. Jornal de Pediatria. 2017 93(4):406-12. doi: 10.1016/j.jped.2016.10.005.

32. Santos PCD, Silva KSD, Silva JAD, Santos C, Duca GFD, Lopes ADS, et al. Change in overweight and obesity over a decade according to sociodemographic factors in Brazilian adolescents. Ciência \& Saúde Coletiva. 2019 24(9):3335-44. doi: 10.1590/141381232018249.29052017.

33. Leal MABF, Lima CEB, Mascarenhas MDM, Rodrigues MTP, Paiva SSC, Sousa CRO, Veloso VR. Associação entre fatores sociodemográficos e comportamentos de risco à saúde cardiovascular de adolescentes brasileiros com 13 a 17 anos: dados da Pesquisa Nacional de Saúde do Escolar 2015. Epidemiologia e Serviços de Saúde. 2019 28:e2018315. doi: 10.5123/s1679-49742019000300008.

34. Bozza R, Campos W, Bacil EDA, Barbosa Filho VC, Hardt JM, Silva PM. Sociodemographic and behavioral factors associated with body adiposity in adolescents. Revista Paulista de Pediatria. 2014 32(3):241-6. doi: 10.1590/1984-0462201432315.

35. World Heath Organization. Global recommendations on physical activity for health. World Health Organization. Geneva, Switzerland: World Health Organization, 2010. 
36. Cardoso LRD, Malbergier A. Problemas escolares e o consumo de álcool e outras drogas entre adolescentes. Psicologia Escolar e Educacional. 2014 18(1):27-34. doi: 10.1590/S1413-85572014000100003.

37. Elicker E, Palazzo LS, Aerts DRGC, Alves GG, Câmara S. Use of alcohol, tobacco and other drugs by adolescents students from Porto Velho-RO, Brazil. Epidemiol. Serv. Saúde [Internet]. 2015 Sep [cited 2021 Aug 17]; 24( 3 ): 399-410. Available from: http://scielo.iec.gov.br/scielo.php? script=sci_artt ext\&pid=S1679-49742015000300006\&lng=en.

38. Nery SSS, de Souza WL, Lucena JMS, dos Santos JC, Nunes AP, Guimarães MCF, et al. Comportamentos de Risco à Saúde em adolescentes: uma associação entre o Tempo de Televisão e uso de álcool. Motricidade. 2020 16(2): 184-95. Doi: 0.6063/motricidade.18278.

39. Brito AMM. Representações sociais, crenças e comportamentos de saúde: um estudo comparativo entre homens e mulheres [dissertação]. Santa Catarina: Universidade Federal de Santa Catarina; 2012.

40. Agathão BT, Reichenheim ME, Moraes CL. Qualidade de vida relacionada à saúde de adolescentes escolares. Ciência \& Saúde Coletiva. 2018 23:659-68. doi: 10.1590/141381232018232.27572016 .

41. Malina RM, Bouchard C, Bar-Or O. Crescimento, maturação e atividade física. 1 ed. São Paulo: Phorte; 2009.

42. Cordeiro R, Arriaga M, Claudino J. Depressão e suporte social em adolescentes e jovens adultos. Revista Iberoamericana de Educación. $2006 \quad 39(6): 1-10 . \quad$ doi: 10.35362/rie3962543.

43. Antunes C, Fontaine AM. Percepção de apoio social na adolescência: análise fatorial confirmatória da escala Social Support Appraisals. Paidéia. 2005 15(32):355-66. doi: 10.1590/S0103-863X2005000300005.
44. Benincasa M. Avaliação da qualidade de vida e uso de drogas em adolescentes do município de São Paulo [tese]. São Paulo: Universidade de São Paulo; 2018.

45. Nery C, Moraes SRA, Novaes KA, Bezerra MA, Silveira PVDC, Lemos A. Effectiveness of resistance exercise compared to aerobic exercise without insulin therapy in patients with type 2 diabetes mellitus: a metaanalysis. Brazilian journal of physical therapy. 2017 21(6):400-15. doi: 10.1016 / j.bjpt.2017.06.004.

\section{Information of this article:}

Recebido: 10/07/2021

Aprovado: 02/08/2021

Publicado: 23/08/2021

Received: 10/07/2021

Approved: 02/08/2021

Published: 23/08/2021

\section{Conflicting Interests}

The authors declare that they have no conflicting interests.

\section{Acknowledgements}

The authors acknowledge professor Mathias Roberto Loch for critical analysis.

Como citar esse artigo / How to cite this article:

Sousa RC, Souza AA, Martins WR, et al. Association between licit drugs, physical activity and health-related quality of life in adolescents in northern Brazil. Arq. Bras. Ed. Fís., Tocantinópolis, v. 4, n. 1, Jan./Jul. p. 107 - 123, 2021. 